\title{
The Heavy Metal Contamination in Shallow Groundwater at Coastal Areas of Surabaya East Java Indonesia
}

\author{
Baskoro Rochaddi 1*, Warsito Atmodjo' , Alfi Satriadi1 , Chrisna Adhi Suryono2, Irwani \\ Irwani ${ }^{2}$ and Sugeng Widada ${ }^{1}$
}

\author{
'Department Oceanography, Faculty of Fisheries and Marine Sciences, Diponegoro University \\ 2Department Marine Science, Faculty of Fisheries and Marine Sciences, Diponegoro University \\ JI. Prof. H. Soedharto, SH., Tembalang, Semarang, Indonesia 50275 \\ Email : rochaddi@ymail.com
}

\begin{abstract}
The present study was conducted to assess the level of heavy metal contamination in shallow aquifer of Surabaya coastal areas. Six heavy metals (Arsenic, Mercury, Chromium, Lead, Cupper and Magnesium) of contaminant have been determined in the shallow groundwater. The samples were then analyzed by using Atomic Absorbent Spectrometry gas and followed by using the method of Standard Method Examination. The result indicated that shallow groundwater in Surabaya has been contaminated by Arsenic (0.243 ppm) and Magnesium (1.262 ppm). Another heavy metal such as Mercury, Chromium, Lead, and Cupper showed bellow detected. This study has proven the presence of heavy metal as specially Arsenic and Magnesium has been contain in shallow aquifer supplies in the coastal areas of Surabaya.
\end{abstract}

Keywords: Heavy Metal, Shallow Groundwater, Arsenic, Magnesium

\section{INTRODUCTION}

Clean water is a basic human need that is important, both as drinking water or other necessities of life, but not all regions have good water resources. Coastal are minimal areas in clean freshwater resources, so problems often arise in coastal areas in terms of meeting the need for clean, fresh water. Groundwater in shallow aquifers is one of the sources of clean water available in coastal areas. Of the 12,827 coastal villages in Indonesia, there are still 7,464 villages that rely on groundwater as a source of drinking water so that the groundwater quality in coastal areas is a critical thing to maintain. Parameters of biological chemical and physical determine the quality of water (Sargaonkar and Deshpande, 2003). The contamination of groundwater is a serious problem (Crévecoeur et al., 2011). In developing worlds, the insufficiency of clean fresh water supplies has a negative impact on public health and the life expectancy of a people (Ravindra and Garg 2007). Changes in the pattern of groundwater use replacing surface water for drinking water in Southeast and South Asia resulted in a reduction in waterborne diseases, however, making an increase in natural exposure to toxic inorganic substances (Bacquart et al., 2015). Due to the toxicity, high bio-accumulative potential and persistence, pollution of heavy metal of water is of severe environmental concern (Pekey et al., 2004). Severe human health impacts such as infertility, skeletal and cardiovascular diseases, and neurotoxicity, etc related with heavy metal exposure in humans (World Health Organization, 2008). Exposure of minerals to human beings results in several kidney and liver problems beside such group of toxicants is believed as a genotoxic carcinogen(Chabukdhara et al., 2017). Some metals are needed for the living organisms function and growth; However, exposure to higher concentrations can be toxic to aquatic life and humans (Ouyang et al., 2002). High levels of toxic metals in groundwater pose a significant risk to users of local resources and the natural environment (Chabukdhara et al., 2017). In addition to sources of geogenic, groundwater metal pollution has been generated because of urbanization and industrialization are quickly 
followed by unplanned, and uncontrolled waste disposal, washing, and percolation from highly contaminated locations, intensive agricultural activities. (Kavcar et al., 2009). More, presently, there is no regulatory standard of metals concentrations in groundwater in many developing countries.

\section{MATERIALS AND METHODS}

The samples of groundwater were taken from six different locations from both urban industrial and agricultural regions of Surabaya and Sidoarjo district during April and June 2018 (Figure 1). The groundwater samples were taken in pre-washed $1000 \mathrm{ml}$ bottles from shallow borewells and dig wells. The samples were stored ice-cold airtight boxes and carried to the laboratory within 12 hours of collection. The analysis of physicochemical was achieved following the standard methods for metal analysis (Rice et al., 2012). $50 \mathrm{ml}$ of water samples were processed with concentrated $\mathrm{HNO} 310 \mathrm{ml}$ at $80 \mathrm{C}$ until the solution became clear (Rice et al., 2012). After filtered through No. 42 Whatman filter paper, the solution with ultrapure water was diluted to $50 \mathrm{ml}$. Analysis of the metal was passed out by an atomic absorption spectrophotometer double-beam.

\section{RESULTS AND DISCUSSIONS}

lons concentrations of six metal in samples of groundwater were taken from six sites during the April to June 2018 have been recorded in the Table (S1). Selected descriptive statistics of heavy metal concentration has been related to the standard of drinking water of (World Health Organization, 2008) in Table 1. Table 1 also shows the number of samples which exceeds (World Health Organization, 2008) regulation values concerning for individually heavy metal. Comparison of the average of each metal clearly shows that some minerals get concentrated and some metals get diluted. This observation will be discussed in more detail in the next section of this research. It was interesting to note that concentration of As in five locations except SK 1 were far above the highest permissible limit as and $M g$ is a nonrelaxable (NR) parameter. Big SD for each metal point to the spread of metal values across the SRB stretch. Further, a meaningful difference between the median and mean values in each case indicates that the distribution is mode off the normal.

In the case of this study 5 samples showed improper drinking water with As content far above the feasibility threshold of 0.01 ppm except at SK1 location. The content of $\mathrm{Mg}$ in six groundwater samples is relatively small or far below the limit of 500 ppm according to drinking water requirements by the regulation of the health minister of the Republic of Indonesia number 492 of 2010.

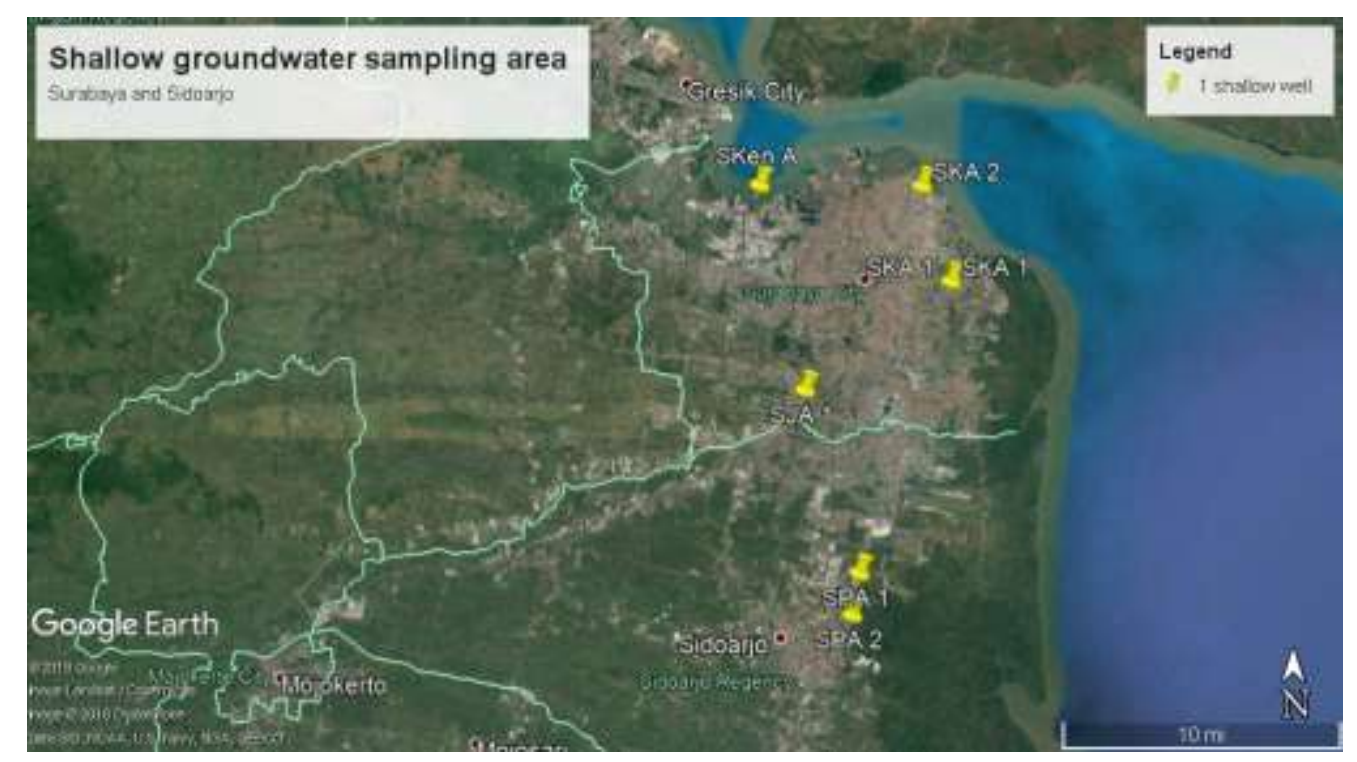

Figure 1. The sampling areas at Surabaya \& Sidoajo coastland areas 
Table 1. Heavy metal on groundwater Surabaya and Sidoarjo

\begin{tabular}{cccc}
\hline Surabaya(code Areas) & Heavy Metal & Concentration $(\mathrm{ppm})$ & SD \\
\hline (SUA1) & $\mathrm{As}$ & 0.102 & 0.2 \\
& $\mathrm{Mg}$ & 2.959 & 0.38 \\
(SUA2) & $\mathrm{As}$ & 0.366 & 0.096 \\
& $\mathrm{Mg}$ & 0.579 & 1.63 \\
(SJA1) & $\mathrm{As}$ & 0.325 & 0.099 \\
& $\mathrm{Mg}$ & 1.74 & 1.129 \\
(SKA1) & $\mathrm{As}$ & 0.272 & 0.086 \\
& $\mathrm{Mg}$ & 0 & 0 \\
(SKA2) & $\mathrm{As}$ & 0.393 & 0.0772 \\
& $\mathrm{Mg}$ & 2.159 & 1.09 \\
(SK1) & $\mathrm{As}$ & 0 & 0 \\
& $\mathrm{Mg}$ & 0.136 & 0.011 \\
\hline
\end{tabular}

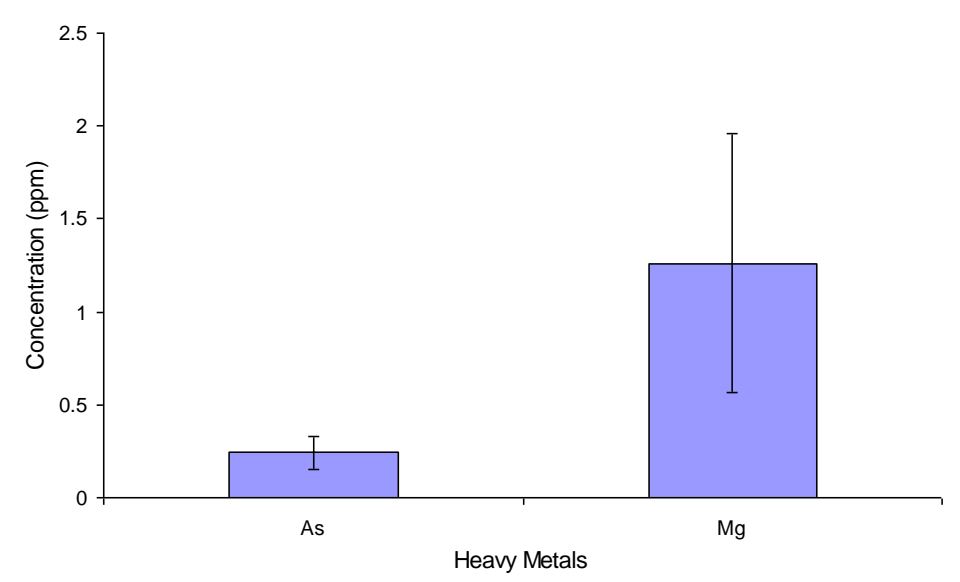

Figure 2. Concentration of metal on groundwater Surabaya and Sidoarjo district

Naturally, the presence of arsenic can be found in soil, air, sediments, and plants. Arsenic dissolved in water in the form of organic and inorganic compounds. Some studies in America and Europe show that the content of arsenic in water naturally in unpolluted conditions is below $0.01 \mathrm{ppm}$. High levels of arsenic in water typically up to 8.5 ppm are found in locations where there is geothermal activity. Arsenic levels in the study sites were found to range from 0.102-0.393 ppm far above the value of $0.01 \mathrm{ppm}$ while the study area was not a geothermal area, indicating that the shallow groundwater had been polluted. Based on the location of the research area, it is an industrial city and a small part of agriculture, so it can be interpreted that the primary source of arsenic pollutants comes from industrial activities (glass, chemical industry, pharmacy).

\section{CONCLUSION}

Arsenic and magnesium are found in shallow groundwater samples in Surabaya and Sidoarjo with varying levels of $0.102-0.393$ $\mathrm{ppm}$ or an average of $0.2916 \mathrm{ppm}$, while the magnesium content ranges from $0.136-2,959$ $\mathrm{ppm}$. The arsenic content which is far above the average natural content of arsenic in water indicates that groundwater in the study area has been polluted by arsenic. Interpreted the primary source of arsenic pollutants is industrial activities in the cities of Surabaya and Sidoarjo.

\section{ACKNOWLEDGMENT}

This article is part of the research which supported by the grant from non APBN 2018 Faculty of Fisheries and Marine Sciences Diponegoro University. 


\section{REFERENCES}

Bacquart, T., Frisbie, S., Mitchell, E., Grigg, L., Cole, C., Small, C. \& Sarkar, B., 2015. Multiple inorganic toxic substances contaminating the groundwater of Myingyan Township, Myanmar: Arsenic, manganese, fluoride, iron, and uranium. Sci.Total Environ. 517:232-245.

Chabukdhara, M., Gupta, S.K., Kotecha, Y. \& Nema, A.K., 2017. Groundwater quality in Ghaziabad district, Uttar Pradesh, India: Multivariate and health risk assessment. Chemosphere, 179:167-178.

Crévecoeur, S., Debacker, V., Joaquim-Justo, C., Gobert, S., Scippo, M.L., Dejonghe, W., Martin, P. \& Thomé, J.P., 2011. Groundwater quality assessment of one former industrial site in Belgium using a TRIAD-like approach. Environ. Poll. 159(10):2461-2466.

Kavcar, P., Sofuoglu, A. and Sofuoglu, S.C., 2009. A health risk assessment for exposure to trace metals via drinking water ingestion pathway. Int. J. Hygiene Environ. Health, 212(2):216-227.

Ouyang, Y., Higman, J., Thompson, J., O'Toole, T. \& Campbell, D., 2002. Characterization and spatial distribution of heavy metals in sediment from Cedar and Ortega rivers subbasin. J. Contaminant Hydrol. 54(1-2):19-35.

Pekey, H., Karakaş, D. \& Bakoglu, M., 2004. Source apportionment of trace metals in surface waters of a polluted stream using multivariate statistical analyses. Mar. Poll. Bull. 49(9-10):809-818.

Ravindra, K. \& Garg, V.K., 2007. Hydrochemical survey of groundwater of Hisar city and assessment of defluoridation methods used in India. Environ. Mon. Ass. 132(1-3):33-43.

Rice, E.W., Baird, R.B., Eaton, A.D. \& Clesceri, L.S., 2012. APHA (American Public Health Association): Standard method for the examination of water and wastewater. Washington DC (US): AWWA (American Water Works Association) and WEF (Water Environment Federation).

Sargaonkar, A. \& Deshpande, V., 2003. Development of an overall index of pollution for surface water based on a general classification scheme in Indian context. Environ. Mon. Ass. 89(1):43-67.

WHO H. World Health Organization guidelines for drinking water quality. World Health Organisation Publication, New York. 2008:197-209 